\title{
Pengaruh penggungkapan tanggung jawab sosial terhadap nilai perusahaan pada perusahaan pertambangan yang terdaftar di bursa efek
}

\author{
Anik Masruroh ${ }^{1}$, Makaryanawati $^{* 1}$ \\ ${ }^{1}$ Fakultas Ekonomi dan Bisnis, Universitas Negeri Malang, Jl. Semarang No 5 Malang, Indonesia
}

\begin{abstract}
Diterima: September 2019 This study aims to determine the effect of corporate social responsibility disclosure (X) on firm value Direvisi: Januari 2020 Disetujui: Januari 2020 (Y). The company is currently not only focused on maximizing profits, but also required to care about social responsibility. Companies can use social responsibility ways to improve competitive advantage, so that the more disclosure made will improve the company's image and the sustainability of the company will be maintained. This study is a quantitative research. Data were collected from 241 Indonesia mining

Koresponding:

Makaryanawati makaryanawati.fe@um.ac. id companies annual reports from 2011 to 2017 . The result show thet corporate social responsibility disclosure has a positive effect on firm value with ISO 26000 Guidance Stanndard on Social Responsibility as a measure of social responsibility disclosure. ISO 26000 has been used by a number of mining companies listed on the Indonesia Stock Exchange as a guide in the implementation of corporate social responsibility

DOI:

http://dx.doi.org/10.17977/ um004v7i12020p67 activities in 2011 to 2017. Mining companies are industries that are very sensitive to environmental pollution, but the concern of mining companies to the environment is low because the average social responsibility disclosure with environmental sub-themes is only 1.68 compared to the sub-themes of community involvement and development that reach 5,20.
\end{abstract}

Keywords: Firm Value, Corporate Social Responsibility

\begin{abstract}
Abstrak
Penelitian ini bertujuan untuk mengetahui pengaruh penggungkapan tanggung jawab sosial (X) terhadap nilai perusahaan $(\mathrm{Y})$. Perusahaan saat ini tidak hanya berfokus pada memaksimal laba, namun juga dituntut peduli terhadap tanggung jawab sosial. Perusahaan dapat menggunakan tanggung jawab sosial sebagai media untuk meningkatkan keunggulan, sehingga semakin banyak penggungkapan yang dilakukan akan meningkatkan image perusahaan dan keberlanjutan perusahaan akan terjaga, Penelitian ini termasuk jenis penelitian kuantitatif. Data dikumpulkan dari annual report 241 perusahaan pertambangan di Indonesia selama periode 2011 sampai 2017. Hasil penelitian menunjukkan bahwa penggungkapan tanggung jawab sosial berpengaruh positif terhadap nilai perusahaan dengan ISO 26000 Guidance Standard on Social Responsibility sebagai pengukuran pengungkapan tanggung jawab sosial. ISO 26000 telah dipergunakan oleh sejumlah perusahaan pertambangan yang terdaftar di Bursa Efek Indonesia sebagai panduan dalam pelaksanaan kegiatan tanggung jawab sosial perusahaan pada tahun 2011 sampai 2017. Perusahaan pertambangan adalah jenis industri yang sangat sensitif terhadap pencemaran lingkungan, namun kepedulian perusahaan pertambangan terhadap lingkungan masih rendah. Hal ini ditunjukkan oleh rata-rata pengungkapan tanggung jawab sosial dengan sub tema lingkungan hanya sebesar 1,68; jika dibandingkan dengan sub tema keterlibatan dan pengembangan masyarakat yang mencapai 5,20.

Kata kunci: Nilai Perusahaan, Pertanggung jawaban Sosial Perusahaan
\end{abstract}

\section{PENDAHULUAN}

Minat tanggung jawab sosial perusahaan semakin meningkat di semua jenis industri publik maupun swasta dari yang berukuran kecil maupun besar dalam beberapa dekade terakhir (Danilovic et al., 2015). Perusahaan menambahkan alokasi sumberdaya untuk kegiatan yang disebut tanggung jawab sosial (Barnea \& Rubin, 2010). Tanggung jawab sosial saat ini telah menjadi elemen penting dari dialog antara perusahaan dan stakeholderyang terus memperhatikan kegiatan perusahaan (Bhattacharya et al., 2009). Perusahaan saat ini tidak hanya berfokus pada memaksimalkan laba, namun juga dituntut peduli dan perhatian terhadap tanggung jawab sosial (Untung, 2009:25). Elkington (1998) menyatakan perusahaan harus memerhatikan aspek ekonomi, lingkungan dan sosial untuk keberlangsungan perusahaan.

Pelaksanaan tanggung jawab sosial perusahaan semakin kuat dengan diterbitkannya Undangundang Nomor 40 Tahun 2007 tentang Perseroan Terbatas. Pasal 74 ayat 1 menjelaskan perseroan 
yang melaksanakan kegiatan usaha di bidang ataupun berkaitan dengan sumberdaya alam wajib melaksanakan kegiatan tanggung jawab sosial dan lingkungan. Bentuk pertanggungjawaban perusahaan tersebut, selain diwujudkan melaui kegiatan sosial, juga dengan melakukan pengungkapan tanggung jawab sosial dalam laporan tahunan perusahaan (annual report) atau laporan terpisah.

Survei mengenai laporan keberlanjutan perusahaan pada tahun 2015 yang dilakukan KPMG memberikan hasil bahwa Indonesia menjadi salah satu negara berkembang yang memiliki tingkat pelaporan tanggung jawab sosial tertinggi di dunia. Adanya keharusan pelaporan tanggung jawab sosial menjadikan Indonesia memiliki tingkat pelaporan hingga 90\% (KPMG, 2015). Pengungkapan tanggung jawab sosial merupakan bentuk transparansi perusahaan agar memperoleh legitimasi dari masyarakat (Kent \& Zunker, 2013).

Tanggung jawab sosial memiliki orientasi kepada stakeholder (Azhar L, 2014). Freeman \& Reed (1983) mendefinisikan stakeholder sebagai pihak yang terkait dengan proses realisasi tujuan perusahaan, termasuk pemilik perusahaan, investor, pelanggan, karyawan, pemasok, pencinta lingkungan dan pemerintah. Perusahaan merupakan bagian dari masyarakat luas (stakeholder), sehingga kegiatan perusahaan harus memperhatikan kepentingan stakeholder yang secara langsung maupun tidak langsung dapat mempengaruhi atau dipengaruhi oleh kegiatan perusahaan (Hadi, 2014: 33). Teori stakeholder menjelaskan bahwa perusahaan merupakan entitas yang tidak hanya beroperasi untuk kepentingan sendiri, namun harus memberikan manfaat bagi stakeholder. Dengan demikian, keberadaan perusahaan sangat dipengaruhi oleh dukungan yang diberikan stakeholder dan diharapkan memberikan manfaat kepada stakeholder.

Dewasa ini investor memiliki ketertarikan terhadap informasi pertanggungjawaban sosial yang disajikan dalam laporan tahunan (Epstein \& Freedman, 1994). Pengungkapan tanggung jawab sosial dalam laporan tahunan berkontribusi dalam memberikan nilai tambah sebagai pertimbangan investor dalam menanamkan modalnya (Widyanti, 2014). Semakin banyak bentuk pertanggungjawaban yang dilakukan perusahaan terhadap lingkungan akan meningkatkan image perusahaan sehingga akan menarik minat investor (Syafrinaldi, 2015). Grimmer \& Bingham (2013) menemukan bahwa perusahaan yang memiliki tanggung jawab sosial yang lebih tinggi akan cenderung diminati oleh konsumen.

Pelaksanaan tanggung jawab sosial berperan penting dalam meningkatkan nilai perusahaan sebagai hasil dari peningkatan penjualan dan profitabilitas melalui loyalitas konsumen yang terbangun dengan cara pelaksanaan kegiatan sosial di lingkungannya (Putri \& Raharja, 2013). Terdapat hal yang bertentangan terkait tanggung jawab sosial perusahaan. Di satu sisi, dapat meningkatkan keunggulan kompetitif perusahaan, namun di sisi lain dapat menjadi pemborosan sumber daya perusahaan jika alokasi sumber daya perusahaan tidak dapat memaksimalkan nilai perusahaan (Jitmaneeroj, 2018; Li et al., 2017).

Penelitian terkait pengungkapan tanggung jawab sosial dan nilai perusahaan telah banyak dilakukan. Hasil penelitan terdahulu menunjukkan pengungkapan tanggung jawab sosial berpengaruh positif terhadap nilai perusahaan (Ardiyanto \& Haryanto, 2017; Fauzi, dkk., 2016; Harjoto \& Laksmana, 2018; Hudoyo \& Juniarti, 2015; Jitmaneeroj, 2018; Jo \& Harjoto, 2011; Khafa \& Laksito, 2015; Li et al., 2017; Maryanti \& Tjahjadi, 2013; Nahda \& Harjito, 2011; Putri \& Raharja, 2013; Retno M \& Prihatinah, 2012; Rosiana, dkk., 2013; W. A. Sari, dkk., 2016; Setyowati, dkk., 2014; Candrayanthi \& Saputra, 2013; Tristianasari \& Fachrurrozie, 2014). Hasil penelitian berbeda dikemukakan oleh Anwar (2016), Aviyanti \& Isbanah (2019), Stacia \& Juniarti (2015), Sudarma \& Darmayanti (2017) dan Widyanti (2014) yang menemukan pengungkapan tanggung jawab sosial tidak mempengaruhi nilai perusahaan. Perbedaan hasil penelitian dimungkinkan karena perbedaan sampel penelitian, yang memiliki perbedaan dalam aspek ukuran perusahaan, profitabilitas, leverage maupun pertumbuhan penjualan. Penelitian sebelumnya menggunakan industri manufaktur, industri konsumsi dan industri perbankan yang terdaftar di Bursa Efek Indonesia.

Berdasarkan perbedaan hasil dari penelitian sebelumnya, maka perlu dilakukan kembali penelitian dengan topik pengungkapan tanggung jawab sosial, serta menggunakan ukuran perusahaan, profitabilitas, leverage, dan pertumbuhan penjualan sebagai variabel kontrol dalam mempengaruhi nilai perusahaan. Penelitian ini mengadopsi ISO 26000 Guidance Standard on Social Responsibility untuk mengungkapkan informasi sosial perusahaan. Penelitian ini dilakukan pada perusahaan pertambangan yang terdaftar di Bursa Efek Indonesia (BEI). Pemilihan pada industri pertambangan disebabkan karena kegiatan utamanya menggunakan sumberdaya alam, sehingga berkewajiban untuk melaksanakan aktivitas tanggung jawab sosial berdasarkan peraturan yang telah ditetapkan. Aktivitas yang dilakukan industri pertambangan ini menyebabkan sekitar 70\% kerusakan lingkungan di Indonesia (https://regional.kompas.com, 28 September 2012). 


\section{KAJIAN PUSTAKA}

\section{Teori Stakeholder}

Menurut Hadi (2014:35) keberadaan perusahaan di lingkungan masyarakat dapat menimbulkan dampak positif maupun negatif. Dampak positif yang muncul dapat dilihat dengan adanya peningkatan ekonomi, sosial dan lingkungan, yang diwujudkan dalam bentuk peningkatan kesejahteraan, infrastruktur, tata sosial, lingkungan dan teknologi. Namun keberadaan perusahaan juga memunculkan dampak negatif, seperti diskriminasi antar golongan, kesenjangan sosial, perpindahan tempat tinggal penduduk, polusi, pencemaran lingkungan, global warming dan sejenisnya. Hal ini menyebabkan perusahaan bertahan tergantung sejauhmana legitimasi stakeholder diberikan pada perusahaan (Meyer \& Rowan, 1977). Legitimasi dari stakehoder atau masyarakat merupakan faktor krusial bagi perusahaan dalam rangka mempertahankan kelangsungan usahanya (Hadi, 2014:88).

Teori stakeholder mengatakan bahwa perusahaan bukanlah entitas yang hanya beroperasi untuk kepentingan sendiri, namun harus memberikan manfaat bagi stakeholdemya (Rosiana, dkk., 2013). Dukungan dari stakeholder sangat menentukan keberadaan perusahaan (Ghozali \& Chariri, 2014: 239), dan sebaliknya perusahaan dituntut untuk memberikan manfaat kepada masyarakat atau stakeholder. Sebagaimana pendapat Gray et al. (1994) dalam Ghozali \& Chariri (2014:439) menjelaskan bahwa kelangsungan hidup perusahaan tergantung pada dukungan stakeholder, sehingga kegiatan perusahaan harus mengarah pada aktivitas yang memperkuat dukungan stakeholder, agar perusahaan segera dapat beradaptasi dengan lingkungan. Sebagai bentuk dialog antara perusahaan dengan stakeholder, maka perusahaan perlu melaporkan pengungkapan tanggung jawab sosialnya.

\section{Nilai Perusahaan}

Nilai perusahaan dikenal juga sebagai enterprise value atau firm value. Nilai perusahaan merupakan nilai wajar perusahaan yang menggambarkan persepsi investor terhadap emiten yang bersangkutan (Hasibuan, dkk., 2016). Nilai perusahaan dapat menjadi indikator untuk menilai kinerja perusahaan dalam aspek ekonomi dan non ekonomi oleh investor (Natanagara \& Juniarti, 2015). Nilai perusahaan yang sudah go publik dapat tercemin melalui harga saham yang beredar dipasar modal. Semakin tinggi harga saham maka semakin tinggi pula nilai perusahaan tersebut di mata para pemegang saham atau calon investor (Dewanti \& Djajadikerta, 2018). Terdapat beberapa rasio keuangan yang dapat digunakan sebagai pengukur nilai pasar perusahaan, yaitu price earning ratio (PER), market to book ratio, market sales ratio, price/cash flow ratio dan Tobin's Q (Sukamulja, 2005).

\section{Tanggung Jawab Sosial Perusahaan (Corporate Social Responsibility)}

Tanggung jawab sosial perusahaan (Corporate social responsibility) merupakan bentuk komitmen perusahaan dalam melaksanakan kewajiban berdasarkan kebijakan dan hukum yang berlaku dengan memperhatikan kepentingan stakeholder dan lingkungan sekitar (Azheri. 2011: 26). Bowen (1953) dalam Carroll (1999) menjelaskan bahwa setiap tindakan perusahaan melibatkan dan mempengaruhi di beberapa segi kehidupan masyarakat, sehingga perusahaan memiliki kewajiban untuk menjalankan perusahaan yang sesuai dengan peraturan, norma dan hukum yang berlaku di masyarakat.

\section{Pengungkapan Tanggung Jawab Sosial}

Pengungkapan tanggung jawab sosial perusahaan sering juga disebut sebagai pengungkapan sosial, akuntansi sosial, pelaporan sosial perusahaan atau corporate social responsibility (Hackston \& Milne, 1996). Pengungkapan tanggung jawab sosial merupakan proses pengkomunikasian dampak-dampak yang ditimbulkan dari kegiatan perusahaan, baik pada dampak ekonomi, sosial dan lingkungan, terhadap kelompok khusus yang berkepentingan dan terhadap masyarakat secara keseluruhan (E. R. Sembiring, 2005).

Hadi (2014:206) menjelaskan laporan tanggung jawab harus dilaporkan dalam Rapat Umum Pemegang Saham (RUPS). Laporan tanggung jawab sosial merupakan laporan aktivitas tanggung jawab sosial yang telah dilakukan oleh perusahaan akibat dampak yang ditimbulkan secara sosial maupun lingkungan. Laporan tersebut menjadi bagian dari laporan tahunan (annual report) yang akan dipertanggungjawabkan di hadapan para pemegang saham dalam RUPS. Laporan tanggung jawab sosial berisikan kegiatan dan program yang telah dilaksanakan oleh perusahaan selama tahun berjalan.

\section{ISO 26000:2010 (Guidance on Social Responsibility)}

ISO 26000 merupakan standar internasional dalam pelaporan keberlanjutan yang dibuat oleh International Organization for Standardisation (ISO). ISO 26000 memberikan panduan tentang 
bagaimana suatu organisasi atau perusahaan dapat beroperasi dengan cara bertanggung jawab secara sosial, yaitu kegiatan bisnis harus dilakukan dengan transparan dan beretika serta mengarah pada kegiatan yang memprioritaskan kesehatan maupun kesejahteraan masyarakat. ISO 26000 mengusulkan tujuh prinsip corporate social responsibility yaitu akuntabilitas, transparansi, perilaku etis, menghormati kepentingan stakeholder, taat aturan hukum dan menghormati norma-norma internasional tentang perilaku serta hak asasi manusia (https://www.iso.org).

\section{Pengembangan Hipotesis Penelitian}

Tanggung jawab sosial merupakan strategi yang dilakukan perusahaan untuk memenuhi kepentingan stakeholder supaya memberikan dukungan penuh terhadap aktivitas perusahaan yang bertujuan untuk meningkatkan kinerja dan laba perusahaan, yang tercermin pada peningkatan nilai perusahaan (Putri \& Raharja, 2013). Stakeholder memiliki kemampuan untuk mempengaruhi pemakaian sumber-sumber ekonomi yang dimiliki perusahaan, sehingga power stakeholder ditentukan oleh besar kecilnya power yang mereka miliki atas sumber tersebut (Ghozali \& Chariri, 2014:440).

Belkaoui \& Karpik (1989) menyatakan bahwa perusahaan dapat menggunakan tanggung jawab sosial sebagai sarana untuk meningkatkan keunggulan kompetitif. Pelaksanaan tanggung jawab sosial berperan penting dalam meningkatkan nilai perusahaan sebagai hasil dari peningkatan penjualan dan profitabilitas melalui loyalitas konsumen yang terbangun dengan cara pelaksanaan kegiatan sosial di lingkungannya (Putri \& Raharja, 2013). Grimmer \& Bingham (2013) memberikan bukti bahwa konsumen lebih menyukai produk dari perusahaan yang melakukan aktivitas tanggung jawab sosial yang lebih tinggi.

Pelaksanaan tanggung jawab sosial mendapatkan penilaian yang baik dari shareholder karena mengurangi risiko ancaman dan pertentangan masyarakat (Waddock \& Graves, 1997). Pengungkapan tanggung jawab sosial dalam laporan tahunan juga menjadikan nilai tambah yang akan dipertimbangkan oleh investor dalam berinvestasi (Widyanti, 2014). Semakin banyak bentuk pertanggungjawaban yang dilakukan perusahaan terhadap lingkungan akan meningkatkan image perusahaan sehingga akan menarik minat investor (Syafrinaldi, 2015).

Teori stakeholder menjelaskan bahwa perusahaan bukan entitas yang hanya beroperasi untuk kepentingan sendiri namun harus memberikan manfaat bagi stakeholder (Rosiana, dkk., 2013). Jika pengungkapan tanggung jawab sosial dihubungkan dengan teori stakeholder, maka praktik pengungkapan tanggung jawab sosial yang dilakukan oleh perusahaan akan meningkatkan kepercayaan, reputasi dan dukungan masyarakat terhadap perusahaan. Dengan demikian kinerja dan nilai perusahaan akan meningkat.

Peningkatan nilai perusahaan juga dapat dipengaruhi oleh faktor fundamental yang ada dalam perusahaan. Ukuran perusahaan memainkan peran penting dalam memberikan keyakinan kepada investor atas kemampuan perusahaan dalam mengelola aset dan mengakses modal. Profitabilitas sebagai indikator kemampuan perusahaan dalam memperoleh keuntungan juga akan mempengaruhi peningkatan nilai perusahaan. Leverage memberikan gambaran kemampuan perusahaan dalam menghasilkan keuntungan yang berasal dari pendanaan hutang. Penggunaan hutang menyebabkan adanya kontrol atas penggunaan dana oleh manajemen, yang pada akhirnya akan meningkatkan kinerja perusahaan. Faktor lain yang dapat mempengaruhi nilai perusahaan adalah pertumbuhan penjualan. Pertumbuhan penjualan menunjukkan adanya peningkatan market share dan merupakan indikator utama aktivitas perusahaan. Beberapa faktor fundamental ini digunakan sebagai variabel kontrol dalam mengetahui pengaruh pengungkapan tanggung jawab sosial terhadap nilai perusahaan.

Argumen teori stakeholder didukung oleh beberapa penelitian terdahulu yang menunjukkan bahwa pengungkapan tanggung jawab sosial berpengaruh terhadap nilai perusahaan (Ardiyanto \& Haryanto, 2017; Harjoto \& Laksmana, 2018; Hudoyo \& Juniarti, 2015; Jitmaneeroj, 2018; Jo \& Harjoto, 2011; Khafa \& Laksito, 2015; Li et al., 2016; Maryanti \& Tjahjadi, 2013; Nahda \& Harjito, 2011; Putri \& Raharja, 2013). Jitmaneeroj (2018) menemukan bahwa terdapat hubungan positif antara tanggung jawab sosial dengan nilai perusahaan di perusahaan Amerika Serikat. Li et al. (2017) juga menemukan adanya hubungan positif antara kinerja tanggung jawab sosial dengan nilai perusahaan. Berdasarkan teori stakeholder dan hasil penelitian terdahulu, maka hipotesis penelitian ini adalah pengungkapan tanggung jawab sosial berpengaruh positif terhadap nilai perusahaan.

\section{METODE}

\section{Populasi dan Sampel}

Data yang digunakan dalam penelitian ini diperoleh dari annual reportmasing-masing perusahaan yang dipublikasikan di website Bursa Efek Indonesia (www.idx.co.id), dan website perusahaan yang menjadi sampel penelitian. Populasi dalam penelitian ini adalah perusahaan pertambangan yang 
Tabel 1. Perhitungan Pemilihan Sampel Penelitian

\begin{tabular}{|c|c|c|}
\hline No. & Keterangan & Jumlah \\
\hline 1. & Perusahaan pertambangan yang listing di tahun BEI 2011-2017 & 266 \\
\hline 2 & $\begin{array}{l}\text { Annual report perusahaan tidak tersedia dalam website perusahaan, } \\
\text { website BEI dan Pusat Data Bisnis (PDB) Fakultas Ekonomi Universitas } \\
\text { Negeri Malang }\end{array}$ & 20 \\
\hline \multirow[t]{2}{*}{3} & $\begin{array}{l}\text { Perusahaan yang tidak megungkapkan informasi tanggung jawab sosial } \\
\text { dalam periode penelitian }\end{array}$ & 5 \\
\hline & Jumlah sampel penelitian & 241 \\
\hline
\end{tabular}

Tabel 2. Variabel Kontrol Penelitian

\begin{tabular}{ll}
\hline \multicolumn{1}{c}{ Variabel } & \multicolumn{1}{c}{ Indikator } \\
Ukuran perusahaan & SIZE $=$ Ln Total Aset \\
Rofitabilitas & ROE $($ return on equity $)=\frac{\text { Laba Bersih }}{\text { Total Ekuitas }}$ \\
Leverage & DER $($ debt to equity ratio $)=\frac{\text { Total Hutang }}{\text { Total Ekuitas }}$ \\
Pertumbuhan Penjualan & Sales Growth $=\frac{\text { Penjualan periode berjalan }- \text { Penjualan periode sebelumnya }}{\text { Penjualan Periode sebelumnya }}$ \\
\hline
\end{tabular}

terdaftar di Bursa Efek Indonesia (BEI) pada tahun 2011 sampai dengan 2017. Teknik pengambilan sampel menggunakan purposive sampling, dengan kriteria yaitu perusahaan yang listing di BEI yang menerbitkan annual report dan menyampaikan informasi tanggung jawab sosial perusahaan selama tahun 2011-2017. Hasil dari pengambilan sampel tersebut dapat disederhanakan dan disajikan dalam bentuk Tabel 1.

\section{Variabel Penelitian}

Variabel dependen dalam penelitian ini adalah nilai perusahaan yang diproksikan dengan Tobin's Q (Chung \& Pruitt, 1994; Sukamulja, 2005). Keuntungan menggunakan Tobin's Q adalah didasarkan pada nilai pasar perusahaan sehingga kurang rentan terhadap distorsi berbasis akuntansi (Bergstresser \& Philippon, 2006), selain itu Tobin's Q sering digunakan untuk mengukur nilai dalam bidang akuntansi, ekonomi dan literasi keuangan (Jo \& Harjoto, 2011). Nilai Tobin's Q yang tinggi menunjukkan semakin baik prospek pertumbuhan perusahaan (Fauzi, dkk., 2016).

$$
\text { Tobin's } \mathrm{Q}=\frac{\text { MVCS }+ \text { PS }+ \text { BVDEBT }}{\text { BVTA }}
$$

Keterangan:

$$
\begin{array}{ll}
\mathrm{Q} & \text { Nilai perusahaan } \\
\mathrm{MVCS} & \text { Nilai pasar saham (market value of all common stock) diperoleh dari hasil } \\
& \text { perkalian harga saham penutupan (closing price) dengan jumlah saham yang } \\
& \text { beredar akhir tahun } \\
= & \text { Nilai buku saham preferen (prefferen stock) } \\
\text { BVPS } & \text { Nilai buku hutang (book value of debt) diperoleh dari hutang jangka pendek } \\
& \text { perusahaan setelah dikurangi asset jangka pendek ditambah nilai buku hutang } \\
\text { BVDEBT } & \text { jangka panjang } \\
= & \text { Nilai buku total aset perusahaan (book value of total assets })
\end{array}
$$

Variabel independen dalam penelitian ini adalah pengungkapan tanggung jawab sosial yang diproksikan dengan Corporate Sosial Responsibility Index (CSRI). CSRI mengadopsi ISO 26000 Guidance Standard on Social Responsibility untuk pengungkapan tanggung jawab sosial perusahaan. CSRI adalah perbandingan antara total skor item yang diungkapkan oleh perusahaan dengan skor item yang diharapkan dapat diperoleh oleh perusahaan. Peneliti melakukan pengamatan terhadap ada atau tidaknya item informasi mengenai tanggung jawab sosial yang diungkapkan dalam annual report masing-masing perusahaan. Setiap elemen item yang diungkapkan akan diberi skor 1 dan jika tidak diungkapkan akan diberi skor 0 .

CSRI = Jumlah item yang diungkapkan perusahaan

$$
\text { Jumlah item yang diharapkan }
$$


Dalam pengujian hipotesis, penelitian ini mempertimbangkan variabel kontrol yang biasa digunakan penelitian terdahulu untuk menguji nilai perusahaan yaitu ukuran perusahaan (Z1), Profitabilitas (Z2), Leverage (Z3) dan Pertumbuhan Penjualan (Z4). Variabel kontrol dalam penelitian ini disajikan pada Tabel 2 .

\section{Pengujian Hipotesis}

Pengujian dilakukan menggunakan analisis regresi linier berganda dengan persamaan regresi sebagai berikut.

$$
\begin{array}{ll}
Y=\alpha+\beta_{1} X+\varepsilon & \text { (Model 1) } \\
Y=\alpha+\beta_{1} X+\beta_{2} Z_{1}+\beta_{3} Z_{2}+\beta_{4} Z_{3}+\beta_{5} Z_{4}+\varepsilon & \text { (Model 2) }
\end{array}
$$

Keterangan:

$\begin{array}{ll}\mathrm{Y} & =\text { Nilai Perusahaan } \\ \mathrm{X} & =\text { Pengungkapan tanggung jawab sosial } \\ \mathrm{Z1} & =\text { Ukuran Perusahaan } \\ \mathrm{Z} 2 & =\text { Profitabilitas } \\ \mathrm{Z} 3 & =\text { Leverage } \\ \mathrm{Z} 4 & =\text { Pertumbuhan Penjualan } \\ \alpha & =\text { Konstanta } \\ \beta 1, \beta 2, \beta 3, \beta 4, \beta 5 & =\text { Koefisien Regresi Variabel } \\ \varepsilon & =\text { Error }\end{array}$

\section{HASIL dan PEMBAHASAN}

\section{Hasil Analisis}

Tabel 3 menunjukkan statistika deskriptif variabel dependen, variabel independen dan variabel kontrol dari penelitian ini.

Nilai mean dari nilai perusahaan menunjukkan bahwa rata-rata nilai perusahaan pertambangan di Indonesia pada tahun 2011-2017 masih rendah yaitu 3,2024. Nilai minimum dari nilai perusahaan adalah -0.32, namun disisi lain perusahaan yang mampu bersaing akan dapat meningkatkan nilai perusahaan yang dalam hal ini dibuktikan dengan nilai maksimum mencapai 397,80. Standar deviation sebesar 25,9158 menunjukkan bahwa perbedaan nilai perusahaan tergolong cukup besar.

Nilai mean dan standar deviation dari pengungkapan tanggung jawab sosial menunjukkan bahwa rata-rata perusahaan pertambangan memiliki pengungkapan tanggung jawab sosial yang rendah dan antar perusahaan tidak jauh berbeda. Nilai mean pengungkapan tanggung jawab sosial perusahaan adalah 0,3265 atau 32,65\% dari total item yang diharapkan diungkapkan. Hal ini mengindikasikan bahwa pengungkapan tanggung jawab sosial di perusahaan pertambangan yang terdaftar di BEI masih rendah.

Pengungkapan tanggung jawab sosial diproksikan dengan Corporate Social Responsibility Index dan mengadopsi ISO 26000 Guidance Standard on Social Responsibility. ISO 26000 mengembangkan tanggung jawab sosial mencakup 7 isu pokok pengungkapan yaitu tata kelola organisasi, praktik ketenagakerjaan, lingkungan, praktik operasi yang adil, masalah konsumen, keterlibatan dan pengembangan masyarakat serta hak asasi manusia (HAM). Rata-rata pengungkapan tanggung jawab sosial berdasarkan sub isu pokok dapat dilihat pada Gambar 1.

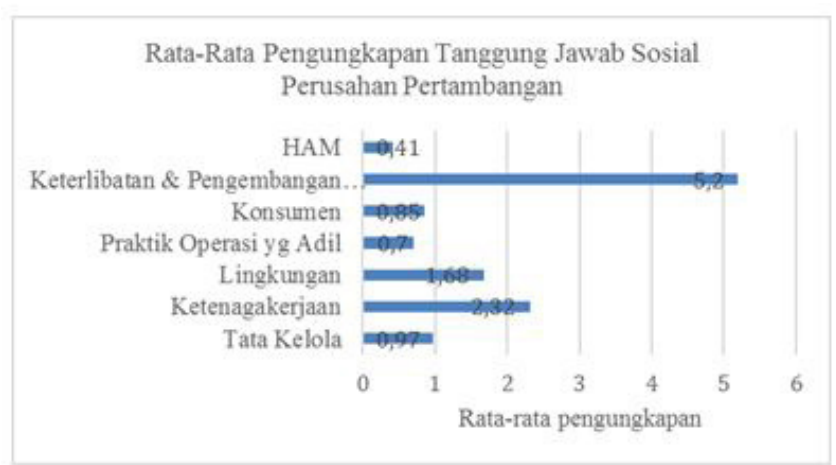

Gambar 1. Rata-Rata Pengungkapan Tanggung Jawab Sosial Berdasarkan Tema Pengungkapan ISO 26000 Pada Tahun 2011-2017 (Sumber: Data yang diolah Peneliti) 
Tabel 3. Statistika Deskriptif

\begin{tabular}{cccccc}
\hline & Variabel & Minimum & Maximum & Mean & Std. Deviation \\
\hline Y & Nilai Perusahaan & -0.32 & 397.80 & 3.2024 & 25.9158 \\
$\mathrm{X}$ & CSRI & 0.05 & 0.73 & 0.3265 & 0.1242 \\
$\mathrm{Z} 1$ & Size & 23.51 & 32.16 & 29.2129 & 1.5344 \\
$\mathrm{Z} 2$ & Profitabilitas & -516.62 & 6.16 & -2.0621 & 33.2888 \\
$\mathrm{Z} 3$ & Leverage & -43.34 & 28.19 & 1.2194 & 5.3148 \\
$\mathrm{Z} 4$ & Sales Growth & -1.00 & 859.38 & 4.0212 & 55.4280 \\
& & & & & \\
\hline
\end{tabular}

Table 4. Hasil Regresi

\begin{tabular}{cccc}
\hline & & Model 1 & Model 2 \\
\cline { 3 - 4 } & (Constant) & -11.885 & 163.280 \\
$\mathrm{X}$ & CSRI & 46.208 & $75.919^{* *}$ \\
$\mathrm{Z} 1$ & Size & & $-6.329^{* *}$ \\
$\mathrm{Z} 2$ & Profitabilitas & & 0.021 \\
$\mathrm{Z} 3$ & Leverage & & 0.068 \\
$\mathrm{Z} 4$ & Sales Growth & & -0.0010 \\
$\mathrm{R} 2$ & & 0.049 & 0.169 \\
& Sig. Uji F & 0.001 & 0.000 \\
\hline
\end{tabular}

**Significant at the 0.01 level (2 p-value $<0.01)$

*Significant at the 0.05 level ( $p$-value $<0.05)$

Tata kelola organisasi memiliki nilai mean 0,97 dan Ketenagakerjaan memiliki nilai mean pengungkapan mencapai 2,32. Keterlibatan dan pengembangan masyarakat memiliki nilai mean tertinggi dalam pengungkapan sebesar 5,20 sedangkan sub tema hak asasi manusia (HAM) hanya mencapai 0,41. Sub tema HAM memiliki nilai mean terendah jika dibandingkan sub tema lainnya, hal tersebut mengindikasikan pengungkapan mengenai hak asasi manusia masih rendah dan bahkan masih terdapat perusahaan yang tidak mengungkapkan informasi tersebut.

Ukuran perusahaan yang menggunakan nilai Ln Total Aset memiliki nilai standard deviation sebesar 1,5344 mengindikasikan bahwa tidak terdapat perbedaan cukup besar pada ukuran perusahaan pertambangan. Nilai mean profitabilitas sebesar -2,0621 disebabkan karena terdapat perusahaan yang mengalami rugi pada periode penelitian. Sementara nilai standard deviation sebesar 33,2888 yang mengindikasikan bahwa nilai profitabilitas antar perusahaan memiliki perbedaan yang cukup tinggi. Nilai mean leverage sebesar 1,2194 menunjukkan bahwa risiko financial distress dalam perusahaan tidak besar. Sementara itu, nilai minimum leverage sebesar $-43,34$ karena terjadi defisiensi ekuitas akibat perusahaan memiliki beban hutang dan bunga yang tinggi serta turunnya penjualan seiring jatuhnya harga komoditas. Sales growth memiliki nilai minimum -1,00; nilai maksimum sebesar 859,38; nilai mean 4,0212 menunjukkan bahwa rata-rata tingkat pertumbuhan penjualan perusahaan mengalami kenaikan 4 kali dibandingkan penjualan tahun sebelumnya. Sementara nilai standard deviation sales growth sebesar 55,4280 menunjukkan bahwa terdapat perbedaan yang cukup besar pertumbuhan penjualan antar perusahaan sampel. Hal ini mengindikasikan bahwa terdapat perusahaan-perusahaan tertentu yang mampu memanfaatkan peluang pasar sehingga mengalami peningkatan penjualan secara signifikan.

\section{Uji Hipotesis}

Pengujian hipotesis dengan analisis regresi berganda, telah melalui pengujian seluruh asumsi klasik dan sudah memenuhi persyaratan. Adapun hasil pengujian regresi dapat dilihat pada Tabel 4. Pengujian pada model 1, menghasilkan nilai konstanta sebesar-11,885, yang mengindikasikan bahwa apabila variabel $\mathrm{X}$ (pengungkapan tanggung jawab sosial) bernilai 0, maka nilai perusahaan sebesar -11,885. Apabila nilai pengungkapan tanggung jawab sosial meningkat sebesar 1\%, maka nilai perusahaan akan meningkat sebesar 46,208\%. Nilai R square sebesar 0,049 mengindikasikan bahwa pengungkapan tanggung jawab sosial mampu menjelaskan $4,9 \%$ variasi nilai perusahaan. Sementara, pengujian pada model 2, menghasilkan nilai $\mathrm{R}$ square sebesar 0,169 mengindikasikan bahwa pengungkapan tanggung jawab sosial dan variabel kontrol yang digunakan dapat menjelaskan 16,9\% variasi nilai perusahaan. Hal ini menunjukkan bahwa variabel kontrol yang digunakan menambah pengaruh pada variasi nilai perusahaan. Hal ini didukung dengan nilai uji statistik F sebesar $0,000<0,05$, yang berarti pengungkapan tanggung jawab sosial dan variabel kontrol secara bersama-sama berpengaruh signifikan terhadap nilai perusahaan. 
Tabel 5. Hasil Uji t

\begin{tabular}{|c|c|c|c|c|c|c|}
\hline & & \multicolumn{2}{|c|}{ Unstandardized Coefficients } & \multirow{2}{*}{$\begin{array}{c}\begin{array}{c}\text { Standardized } \\
\text { Coefficients }\end{array} \\
\text { Beta }\end{array}$} & \multirow{2}{*}{$\mathbf{t}$} & \multirow{2}{*}{ Sig } \\
\hline & & B & Std. Error & & & \\
\hline \multirow{5}{*}{$\mathrm{X}$} & MODEL 1 & & & & & \\
\hline & (Constant) & -11.885 & 4.595 & & -2.586 & 0.010 \\
\hline & CSRI & 46.208 & 13.157 & 0.222 & 3.512 & 0.001 \\
\hline & MODEL 2 & & & & & \\
\hline & (Constant) & 163.280 & 30.379 & & 5.375 & 0.000 \\
\hline $\mathrm{X}$ & CSRI & 75.919 & 13.426 & 0.364 & 5.655 & 0.000 \\
\hline $\mathrm{Z1}$ & Size & -6.329 & 1.086 & -0.375 & -5827 & 0.000 \\
\hline $\mathrm{Z} 2$ & Profitabilitas & 0.021 & 0.046 & 0.027 & 0.461 & 0.646 \\
\hline $\mathrm{Z3}$ & Leverage & 0.068 & 0.291 & 0.014 & 0.236 & 0.814 \\
\hline $\mathrm{Z} 4$ & Sales Growth & -0.0010 & 0.028 & 0.002 & -0.035 & 0.972 \\
\hline
\end{tabular}

Hasil uji t pada tabel 5 menunjukkan bahwa variabel $\mathrm{X}$ memiliki nilai sig. $0,000<0,05$ dan koefisien bertanda positif $\left(^{+}\right)$yang berarti pengungkapan tanggung jawab sosial berpengaruh positif terhadap nilai perusahaan. Dengan demikian hipotesis yang menyatakan bahwa pengungkapan tanggung jawab sosial berpengaruh positif terhadap nilai perusahaan tidak dapat ditolak.

Variabel kontrol ukuran perusahaan (size) memiliki nilai sig. 0,000<0,05 dan koefisien bertanda negatif, sehingga dapat disimpulkan bahwa variabel kontrol ukuran perusahaan berpengaruh negatif terhadap nilai perusahaan. Hasil uji t variabel profitabilitas, leverage dan pertumbuhan penjualan (sales growth) memiliki nilai sig. $>0,05$, sehinga dapat disimpulkan bahwa variabel kontrol profitabilitas, leverage dan pertumbuhan penjualan tidak berpengaruh terhadap nilai perusahaan.

\section{Pengaruh Pengungkapan Tanggung Jawab Sosial Perusahaan terhadap Nilai Perusahaan}

Penelitian ini memberikan hasil bahwa pengungkapan tanggung jawab sosial berpengaruh positif terhadap nilai perusahaan, yang berarti semakin tinggi pengungkapan tanggung jawab sosial perusahaan, maka semakin tinggi nilai perusahaan. Hasil penelitian ini mendukung penelitian terdahulu yang dilakukan oleh Ardiyanto \& Haryanto (2017), Fauzi, dkk. (2016), Harjoto \& Laksmana (2018), Hudoyo \& Juniarti (2015), Jitmaneeroj (2018), Jo \& Harjoto (2011), Khafa \& Laksito (2015) Li et al. (2017), Maryanti \& Tjahjadi (2013), Nahda \& Harjito (2011), Putri \& Raharja (2013), Retno M \& Prihatinah (2012), Rosiana, dkk. (2013), W. A. Sari, dkk. (2016), Setyowati, dkk. (2014), Candrayanthi \& Saputra (2013) dan Tristianasari \& Fachrurrozie (2014).

Tanggung jawab sosial sangat berkaitan erat dengan keberlangsungan usaha suatu perusahaan. Perusahaan melakukan tanggung jawabnya tidak hanya terbatas kepada kepentingan ekonomi pemegang saham (shareholders) tetapi juga harus memperhatikan dimensi sosial dan lingkungan yang menjadi tempat operasi perusahaan (Candrayanthi \& Saputra, 2013). Apabila perusahaan melakukan tanggung jawab tersebut, akan menjamin keberlangsungan usahanya.

Penelitian ini menggunakan perusahaan pertambangan sebagai obyek penelitian. Perusahaan pertambangan adalah jenis industri yang menggunakan sumber daya alam dalam kegiatan operasionalnya, sehingga berpotensi melakukan pencemaran lingkungan (C. L. Sembiring, 2017). Salah satu dampak kerusakan lingkungan yang diakibatkan oleh kegiatan pertambangan adalah timbulnya lubang galian dan tambang serta pencemaran lingkungan di sekitar area pertambangan. Kerusakan lingkungan akibat kegiatan operasional perusahaan mendorong perusahaan untuk melaksanakan kegiatan tanggung jawab sosial. Kegiatan tanggung jawab sosial yang dilakukan oleh perusahaan pertambangan terbagi dalam bidang lingkungan hidup, ketenagakerjaan, kesehatan dan keselamatan kerja, pengembangan sosial dan kemasyarakatan serta tanggung jawab sosial terhadap konsumen. Contoh kegiatan bidang lingkungan hidup adalah pemanfaatan area bekas tambang untuk peternakan sapi, peternakan ayam kampung dan area Telaga Batu Arang sebagai tempat wisata konservasi lingkungan, yang direalisasikan oleh PT. Kaltim Prima Coal.

ISO 26000 merupakan salah satu panduan yang dipergunakan perusahaan pertambangan dalam mengungkapan tanggung jawab sosial. ISO 26000 mengembangkan tanggung jawab sosial mencakup 7 isu pokok pengungkapan dan dijabarkan dalam 38 item pengungkapan. Penelitian ini menemukan terdapat sejumlah perusahaan yang menggunakan ISO 26000 menjadi panduan dalam pelaporan tanggung jawab sosial di laporan tahunan perusahaan (annual report). Perusahaan tersebut antara lain 
PT. Aneka Tambang Tbk, PT. Bumi Resources Tbk, PT. Vale Indonesia Tbk, PT. Dian Swastika Sentosa Tbk, PT. Golden Energy Mines Tbk, PT. Indo Tambangraya Megah Tbk, PT. Tambang Batubara Bukit Asam Tbk, PT Timah Tbk dan PT. Elnusa Tbk. Sementara perusahaan pertambangan yang lain menggunakan Global Reporting Initiative (GRI) sebagai panduan pengungkapan kegiatan tanggung jawab sosialnya.

Perusahaan pertambangan melaporkan pengungkapan tanggung jawab sosial dengan rata-rata sebesar 0,32 selama periode penelitian. Sub tema hak asasi manusia (HAM) menjadi informasi yang cenderung masih sedikit perusahaan yang melakukan pengungkapan dengan rata-rata sebesar 0,41, sedangkan sub tema keterlibatan pengembangan masyarakat dan ketenagakerjaan menjadi informasi yang seringkali diungkapkan dalam laporan tahunan perusahaan (annual report) dengan nilai ratarata sebesar 5,20 dan 2,32. Di sisi lain rata-rata pengungkapan tanggung jawab sosial dengan sub tema lingkungan hanya sebesar 1,68. Hal ini bertolak belakang dengan kondisi perusahaan pertambangan yang rentan menimbulkan pencemaran dan kerusakan lingkungan.

Kegiatan tanggung jawab sosial yang berkaitan dengan sub tema keterlibatan dan pengembangan masyarakat yang dilakukan meliputi pemberian bantuan korban bencana alam, bantuan pendidikan dan atau pelatihan, bantuan peningkatan kesehatan, bantuan pengembangan sarana dan atau sarana umum, bantuan sarana ibadah, bantuan pelestarian alam serta bantuan sosial kemasyarakatan dalam rangka pengentasan kemiskinan. Dari sisi sub tema ketenagakerjaan kegiatan tanggung jawab sosial yang dilakukan yaitu kegiatan pembinaan dan pengawasan internal keselamatan dan kesehatan kerja (K3) yang dilakukan di setiap objek produksi, pendidikan dan pelatihan yang diadakan untuk memenuhi kompetensi karyawan, adanya sosialisasi pentingnya menjaga kesehatan kerja, pelaksanaan audit internal dan eksternal untuk bahan evaluasi perbaikan sistem manajemen keselamatan serta adanya kegiatan pelatihan penanggulangan insiden kecelakaan kerja dengan dibentuknya standard operating procedure. Pengungkapan mengenai hak asasi manusia (HAM) merupakan informasi yang cenderung sedikit pengungkapannya bahkan terdapat sejumlah perusahaan yang tidak memberikan informasi tersebut. Hal ini menunjukkan bahwa kesadaran masyarakat mengenai hak asasi manusia masih rendah.

Perusahaan yang memiliki informasi pengungkapan tertinggi selama periode penelitian adalah PT. Timah Tbk, PT Aneka Tambang Tbk dan PT. Tambang Batubara Bukit Asam Tbk, sedangkan PT. Perdana Karya Perkasa Tbk, PT. Garda Tujuh Buana Tbk dan PT. Cita Mineral Investindo Tbk menjadi perusahaan pertambangan yang paling rendah dalam pengungkapan tanggung jawab sosial. Ketiga perusahaan yang memiliki tingkat pengungkapan tanggung jawab sosial tertinggi adalah perusahaan yang berstatus Badan Usaha Milik Negara (BUMN). Pada tahun 2017 PT Tambang Batubara Bukit Asam resmi bergabung bersama PT Aneka Tambang Tbk dan PT Timah Tbk dalam holding BUMN Pertambangan PT Inalum (Persero) sebagai holding company.

BUMN melaksanakan kegiatan tanggung jawab sosial kepada masyarakat melalui Program Kemitraan dan Bina Lingkungan (PKBL) (www.bumn.go.id, 21 Mei 2019). PKBL dilaksanakan dengan dasar Undang-Undang Nomor 19 Tahun 2003 tentang Badan Usaha Milik Negara (BUMN) serta Peraturan Menteri BUMN Nomor 08/MBU/2013 Setiap perseroan atau badan dapat menyisihkan laba untuk pendanaan program maksimal sebesar $2 \%$ dari laba bersih untuk program kemitraan dan $2 \%$ dari laba bersih untuk program bina lingkungan. Hal ini menjadikan pengungkapan tanggung jawab sosial perusahaan pertambangan yang berstatus sebagai BUMN memiliki tingkat penggungkapan tanggung jawab sosial yang lebih tinggi.

Pengungkapan tanggung jawab sosial perusahaan mengalami peningkatan selama periode penelitian. Hal tersebut menunjukkan bahwa kesadaran perusahaan mengenai tanggung jawab sosial semakin meningkat. Dewasa ini minat pelaksanaan tanggung jawab sosial semakin meningkat di semua jenis industri publik maupun swasta (Dalilovic et al., 2015). Perkembangan rata-rata pengungkapan tanggung jawab sosial selama tahun 2011 sampai 2017 dapat dilihat pada gambar 2.

Tanggug jawab sosial saat ini telah menjadi elemen yang penting, karena merupakan sarana dialog antara perusahaan dan stakeholder yang terus memperhatikan kegiatan perusahaan (Bhattacharya et al., 2009). Perusahaan yang melakukan pengungkapan tanggung jawab sosial dapat meningkatkan atau mempertahankan keunggulan kompetitifnya (Belkaoui \& Karpik, 1989). Pelaksanaan tanggung jawab sosial dapat meningkatkan nilai perusahaan sebagai konsekuensi dari peningkatan penjualan dan profitabilitas. Peningkatan penjualan ini terbangun karena loyalitas konsumen kepada perusahaan yang melakukan kegiatan sosial di lingkungannya (Putri \& Raharja, 2013).

Pelaksanaan tanggung jawab sosial mendapatkan penilaian yang baik dari stakeholder karena mengurangi risiko ancaman dan pertentangan dari masyarakat (Waddock \& Graves, 1997). Pengungkapan tanggung jawab sosial dalam laporan tahunan berkontribusi membuat nilai tambah, yang dapat dijadikan sebagai dasar pertimbangan investor dalam menanamkan modalnya (Widyanti, 


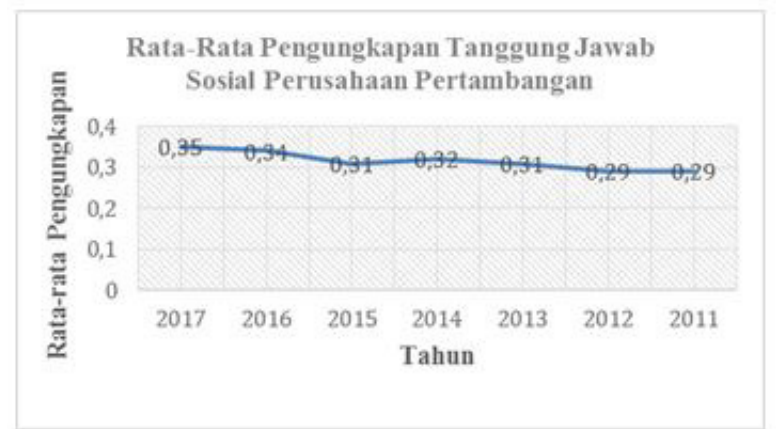

Gambar 2. Rata-rata Pengungkapan Tanggung Jawab Sosial Perusahaan Pertambangan Pada Tahun 2011-2017 (Sumber: Data yang diolah peneliti)

2014). Semakin banyak bentuk pertanggungjawaban yang dilakukan perusahaan terhadap lingkungan akan meningkatkan image perusahaan sehingga akan menarik minat investor (Syafrinaldi, 2015).

Hasil ini sesuai dengan Teori stakeholder yang menjelaskan bahwa perusahaan bukan entitas yang hanya beroperasi untuk kepentingan sendiri namun harus memberikan manfaat bagi stakeholder (Rosiana, dkk., 2013). Tanggung jawab sosial merupakan strategi perusahaan untuk memenuhi keinginan stakeholder sehingga akan memberikan dukungan penuh terhadap aktivitas perusahaan yang bertujuan untuk menaikkan kinerja dan mencapai laba, yang selanjutnya akan menaikkan nilai perusahaan (Putri \& Raharja, 2013). Stakeholder memiliki kemampuan untuk mempengaruhi pemakaian sumber-sumber ekonomi yang dimiliki perusahaan, sehingga power stakeholder ditentukan oleh besar kecilnya power yang mereka miliki atas sumber tersebut (Ghozali \& Chariri, 2014:440).

\section{Variabel Kontrol}

Penelitian ini memberikan hasil bahwa variabel kontrol ukuran perusahaan berpengaruh negatif terhadap nilai perusahaan, sedangkan profitabilitas, leverage dan pertumbuhan penjualan tidak berpengaruh terhadap nilai perusahaan. Gobel (2013) dalam Natanagara \& Juniarti (2015) berpendapat bahwa ukuran perusahaan berdampak negatif terhadap nilai perusahaan karena semakin besar ukuran perusahaan maka semakin besar kapasitas perusahaan, sehingga perusahaan semakin sulit untuk mengelola dan mengendalikan sistem operasional perusahaan. Selain itu, semakin besar perusahaan maka semakin besar pula biaya untuk mengendalikan operasional perusahaan sehingga return yang diterima shareholder semakin kecil. Hal ini mengakibatkan investor merespon negatif harga saham perusahaan yang berkategori besar.

Penelitian ini membuktikan bahwa leverage yang diproksikan oleh debt to equity ratio (DER) tidak berpengaruh terhadap nilai perusahaan. Investor tidak menjadikan DER sebagai indikator pengambilan keputusan investor untuk membeli saham. Investor melihat bagaimana prospek perusahaan melalui pengelolaan dana secara efisien dan efektif, serta melihat kemampuan perusahaan dalam mengelola modal eksternal untuk menciptakan keuntungan (Hudoyo \& Juniarti, 2015; Dewanti \& Djajadikerta, 2018).

Demikian juga dengan variabel kontrol profitabilitas, yang tidak berpengaruh terhadap nilai perusahaan. Nilai mean profitabilitas sebesar -2,0621 menunjukkan bahwa rata-rata perusahaan pertambangan mengalami kerugian selama periode pengamatan, selain itu nilai standar deviation sebesar 33,28888 mengindikasikan bahwa profitabilitas antar perusahaan memiliki perbedaan yang tinggi. Kerugian yang diderita oleh perusahaan pertambangan selama periode pengamatan akibat adanya kebijakan pemerintah mengenai larangan kegiatan ekspor mineral mentah yang diberlakukan pada tahun 2014 serta fluktuasi harga komoditas pertambangan (https://bisnis.tempo.co,3 Juni 2014). Temuan profitabilitas yang tidak berpengaruh terhadap nilai perusahaan mengindikasikan investor tidak melihat profitabilitas (ROA) dalam berinvestasi, namun investor melihat pola pergerakan harga saham yang merefleksikan fundamental perusahaan.

Penelitian ini menemukan bahwa pertumbuhan penjualan tidak berpengaruh terhadap nilai perusahaan. Hal ini menunjukkan bahwa investor tidak melihat pertumbuhan penjualan dalam berinvestasi, karena pertumbuhan penjualan bukan pendapatan bersih penjualan (Dramawan, 2015). Pertumbuhan penjualan merupakan hasil yang belum final karena pendapatan masih harus dikurangi dengan biaya operasi (Limbong \& Chabachib, 2016). Selain itu, penelitian ini menemukan adanya beberapa sampel perusahaan yang memiliki nilai penjualan nol akibat adanya kebijakan larangan ekspor. Hal tersebut menjadi penyebab nilai mean dari pertumbuhan penjualan sebesar 4,0212 dan pertumbuhan penjualan tidak dapat mempengaruhi nilai perusahaan. 


\section{SIMPULAN}

Penelitian ini menguji pengaruh variabel pengungkapan tanggung jawab sosial terhadap nilai perusahaan pada perusahaan pertambangan di Indonesia tahun 2011-2017 berdasarkan teori stakeholder. Penelitian ini memberikan bukti bahwa pengungkapan tanggung jawab sosial berpengaruh terhadap nilai perusahaan. Hasil penelitian ini konsisten dengan penelitian terdahulu yang menemukan pengaruh positif pengungkapan tanggung jawab sosial terhadap nilai perusahaan. Aktivitas sosial perusahaan yang memperhatikan lingkungan sekitar direspon positif oleh investor, sehingga menaikan harga saham perusahaan sebagai indikator dari nilai perusahaan. Hal ini sesuai dengan teori stakeholder yang menjelaskan bahwa perusahaan tidak boleh hanya mengutamakan perolehan laba, tetapi juga harus memberikan manfaat bagi stakeholder, sehingga perusahaan harus melaksanakan kegiatan tanggung jawab sosial.

Tanggung jawab sosial sangat berkaitan erat dengan keberlangsungan atau sustainability perusahaan. Perusahaan pertambangan adalah jenis industri yang mengeksplorasi sumber daya alam, sehingga sangat potensial merusak dan mencemari lingkungan, namun kepedulian perusahaan pertambangan terhadap lingkungan tidak terlalu tinggi. Hal ini didukung oleh data penelitian, ratarata pengungkapan tanggung jawab sosial dengan sub tema lingkungan hanya sebesar 1,68. Angka ini jauh lebih kecil jika dibandingkan dengan sub tema keterlibatan dan pengembangan masyarakat yang mencapai 5,20.

Penelitian ini mengunakan ISO Guidance on Social Responsibility sebagai indikator pengukuran variabel pengungkapan tanggung jawab sosial sehingga terdapat perbedaan persepsi dalam mengidentifikasi tema dan item pengungkapan tanggung jawab sosial yang tersaji dalam laporan tahunan (annual report) perusahaan. Pengambilan data pengungkapan tanggung jawab sosial dari laporan tahunan (annual report) karena hanya beberapa perusahaan yang menyusun sustainability report.

Saran untuk penelitian selanjutnya adalah melibatkan seluruh sektor industri dengan data pengungkapan tanggung jawab sosial diambil dari sustainability report agar data lebih lengkap. Penelitian selanjutnya dapat menggunakan studi komparatif antar sektor industri dalam meneliti pengungkapan tanggung jawab sosial perusahaan, sehingga dapat memperkaya literatur.

\section{DAFTAR RUJUKAN}

Anwar. (2016). Kajian Kinerja Keuangan dan Corporate Social Responsibility (CSR) Terhadap Nilai Perusahaan Pada Bank yang Terdaftar di Bursa Efek Indonesia Periode 2011-2015. Balance, XIII(2). Retrieved from http://journal.um-surabaya.ac.id/index.php/balance/article/view/1330.

Ardiyanto, T., \& Haryanto. (2017). Pengaruh Pengungkapan Corporate Social Responsibility terhadap Nilai Perusahaan Dengan Kinerja Keuangan Sebagai Variabel Intervening. Diponegoro Journal of AccountingJournal of Accounting, 6(4), 1-15. Retrieved from https://ejournal3.undip.ac.id/ index.php/accounting/article/view/18687.

Aviyanti, S. C., \& Isbanah, Y. (2019). Pengaruh eco-efficiency, corporate social responsibility, ownership concentration, dan cash holding terhadap nilai perusahaan sektor consumer goods di bei periode 2011-2016. Jurnal Ilmu Manajemen, 71), 77-84. Retrieved from https:// jurnalmahasiswa.unesa.ac.id/index.php/jim/article/view/25114.

Azhar L, A. (2014). Pengaruh Elemen Corporate Governance terhadap Luas Pengungkapan Corporate Social Responsiblity. Jurnal Akuntansi, 3(1), 54-71. Retrieved from https://ejournal.unri.ac.id/ index.php/JA/article/view/2535/0.

Azheri, B. (2012). Corporate Social Responsibility: Dari Voluntary Menjadi Mandator. Jakarta: Rajawali Pers.

Barnea, A., \& Rubin, A. (2010). Corporate Social Responsibility as a Conflict Between Shareholders. Journal of Business Ethics, 97(1), 71-86. https://doi.org/10.1007/s10551-010-0496-z.

Belkaoui, A., \& Karpik, P. G. (1989). Determinants of the Corporate Decision to Disclose Social Information. Accounting; Auditing and Accountability Journal, 2(1). https://doi. org/10.1108/09513578910132240.

Bergstresser, D., \& Philippon, T. (2006). CEO Incentives and Earnings Management. Journal of Financial Economics, 80, 511-529. https://doi.org/10.1016/j.jfineco.2004.10.011. 
Bhattacharya, C. B., Korschun, D., \& Sen, S. (2009). Strengthening Stakeholder-company Relationships Through Mutually Beneficial Corporate Cocial Responsibility Initiatives. Journal of Business Ethics, 85(SUPPL. 2), 257-272. https://doi.org/10.1007/s10551-008-9730-3.

Carroll, A. B. (1999). Corporate Social Responsibility : Evolution of a Definitional Construct. Business \& Society, 38(3), 268-295. https://doi.org/10.1007/BF01216493.

Chung, K. H., \& Pruitt, S. W. (1994). Simple of Tobin's Approximation q. Financial Management, 23(3). https://doi.org/DOI: 10.2307/3665623.

Danilovic, M., Hensbergen, M., Hoveskog, M., \& Zadayannaya, L. (2015). Exploring Diffusion and Dynamics of Corporate Social Responsibility. Corporate Social Responsibility and Environmental Management, 22(3), 129-141. https://doi.org/10.1002/csr.1326.

Dewanti, M. P. R. P., \& Djajadikerta, H. (2018). Pengaruh Kinerja Keuangan dan Tata Kelola Perusahaan Terhadap Nilai Perusahaan pada Industri Telekomunikasi di Bursa Efek Indonesia. Jurnal Akuntansi Maranatha, 191), 98-116. Retrieved from http:/journal.maranatha.edu/index. php/jam/article/view/932.

Dramawan, I. D. K. A. (2015). Pengaruh Risiko Keuangan dan Pertumbuhan Penjualan Pada Profitabilitas dan Nilai Perusahaan Property. Buletin Studi Ekonomi, 20(2), 158-167. Retrieved from https://ojs. unud.ac.id/index.php/bse/article/view/18840.

Elkington, J. (1998). Accounting for The Triple Bottom Line”. Measuring Business Excellence, 2(3), 18-22. https://doi.org/10.1108/eb025539.

Epstein, M. J., \& Freedman, M. (1994). Social Disclosure and the Individual Investor. Accounting, Auditing \& Accountability Journal, 74), 94-109. https://doi.org/10.1108/09513579410069867.

Fauzi, A. S., Suransi, N. K., \& Alamsyah. (2016). Pengaruh GCG dan CSR terhadap Nilai Perusahaan dengan Profitabilitas sebagai Variabel Pemoderasi. Jurnal InFestasi, 12(1), 1-19. Retrieved from http://journal.trunojoyo.ac.id/infestasi/article/view/1797.

Freeman, R. E., \& Reed, D. L. (1983). Stockholders and Stakeholders: A New Perspective on Corporate Governance. California Management Review, 25(3), 88-106. https://doi.org/10.230 7/41165018.

Ghozali, I., \& Chariri, A. (2014). Teori Akuntamsi International Financial Reporting System (IFRS). Semarang: Badan Penerbit Universitas Diponegoro.

Grimmer, M., \& Bingham, T. (2013). Company environmental performance and consumer purchase intentions. Journal of Business Research, 66(10), 1945-1953. https://doi.org/10.1016/j.jb usres.2013.02.017.

Hadi, N. (2014). Corporate Social responsibility. Yogyakarta: Graha Ilmu.

Hackston, D., \& Milne, M. J. (1996). Some Determinants of Social and Environmental Disclosures in New Zealand Companies. Accounting, Auditing \& Accountability Journal, 9(1), 77-108. https:// doi.org/https://doi.org/10.1108/09513579610109987.

Harjoto, M., \& Laksmana, I. (2018). The Impact of Corporate Social Responsibility on Risk Taking and Firm Value. Journal of Business Ethics, 151(2), 353-373. https://doi.org/10.1007/s10551-016-3202-y.

Hasibuan, V., AR, M. D., \& NP, N. Gw. E. (2016). Pengaruh Leverage dan Profitabilitas Terhadap Nilai Perusahaan (Studi pada Perusahaan Property dan Real Estate yang Terdaftar di Bursa Efek Indonesia Periode Tahun 2012-2015). Jurnal Administrasi Bisnis (JAB), 39(1), 1-13. Retrieved from http://administrasibisnis.studentjournal.ub.ac.id/index.php/jab/article/view/ 1544.

Hudoyo, O., \& Juniarti. (2015). Pengaruh Corporate Social Responsibility terhadap Nilai Perusahaan pada Sub Sektor Industri Metal, Pakan Ternak, Kertas, dan Kayu yang Terdaftar di BEI 2009-2013. Business Accounting Review, 3(2), 121-130. Retrieved from http://publication.petra .ac.id/index.php/ akuntansi-bisnis/article/view/3856/3460.

Jitmaneeroj, B. (2018). A latent variable analysis of corporate social responsibility and firm value. Managerial Finance, 44(4), 478-494. https://doi.org/10.1108/MF-08-2017-0303.

Jo, H., \& Harjoto, M. A. (2011). Corporate Governance and Firm Value: The Impact of Corporate Social Responsibility. Journal of Business Ethics, 103(3), 351-383. https://doi.org/10.1007/s10551-011-0869-y. 
Kent, P., \& Zunker, T. (2013). Attaining Legitimacy by Employee Information in Annual Reports. Accounting, Auditing and Accountability Journal, 26(7), 1072-1106. https://doi.org/10.1108/ AAAJ03-2013-1261.

Khafa, L., \& Laksito, H. (2015). Pengaruh Csr, Ukuran Perusahaan, Leverage, Dan Keputusan Investasi Pada Kinerja Keuangan Perusahaan Dan Nilai Perusahaan. Diponegoro Journal of Accounting, 4(4), 1-13. Retrieved from https://ejournal3.undip.ac.id/index.php/accounting/article/view/9575.

Li, D., Xin, L., Chen, X., \& Ren, S. (2016). Corporate social responsibility, media attention and firm value: empirical research on Chinese manufacturing firms. Quality and Quantity, 51(4), 15631577. https://doi.org/10.1007/s11135-016-0352-z.

Maryanti, E., \& Tjahjadi, B. (2013). Analisis Corporate Social Responsibility dan Good Corporate Governance Terhadap Kinerja Keuangan yang Mempengaruhi Nilai Perusahaan Manufaktur yang Terdaftar di Bursa Efek Indonesia. Jurnal Ekonomi Dan Bisnis, 23(1), 47-62. Retrieved from https://e-journal.unair.ac.id/JEBA/article/view/4534.

Meyer, J. W., \& Rowan, B. (1977). Institutionalized Organizations: Formal Structure as Myth and Ceremony. American Journal of Sociology, 83(2), 340-363. https://doi.org/10.1086/226550.

Nahda, K., \& Harjito, D. A. 2011. Pengaruh Corporate Social Responsibility terhadap Nilai Perusahaan dengan Corporate Governance sebagai Variabel Moderasi. Jurnal Siasat Bisnis, 15(1), 1-12. https://doi.org/10.20885/jsb.vol15.iss1.art1.

Natanagara, D. M., \& Juniarti. (2015). Pengaruh Pengungkapan Corporate Social Responsibility terhadap Respon Nilai Perusahaan pada Subsektor Semen, Keramik, Plastik, dan Kimia. Business Accounting Review, 3(2), 271-280. Retrieved from http://publication.petra.ac.id / index.php/akuntansi-bisnis/article/view/3871/3475.

Putri, H. C. M., \& Raharja, S. (2013). Pengaruh Corporate Social Responsibility terhadap Nilai Perusahaan dengan Kepemilikan Manajerial sebagai Variabel Moderating. Diponegoro Journal of Accounting, 2(3), 1-15. Retrieved from https://ejournal3.undip.ac.id/index.php /accounting/ article/view/3412.

Retno M, R. D., \& Prihatinah, D. (2012). Pengaruh Good Corporate Governance dan Pengungkapan Corporate Social Responsibility Terhadap Nilai Perusahaan. Jurnal Nominal, 1(5), 12-14. Retrieved from https://journal.uny.ac.id/index.php/nominal/article/view/1000.

Rosiana, G. A. M. E., Juliarsa, G., \& Sari, M. M. R. (2013). Pengaruh Pengungkapan Corporate Sosial Responsibility Terhadap Nilai Perusahaan Dengan Profitabilitas Sebagai Variabel Pemoderasi. Jurnal Akuntansi, 5(3), 723-738. Retrieved from https://ojs.unud.ac.id/ index.php/Akuntansi/ article/view/7666.

Sari, P. Y., \& Priantinah, D. (2018). Pengaruh Kinerja Keuangan Dan Corporate Social Responsibility (CSR) Terhadap Nilai Perusahaan Pada Bank Yang Terdaftar Di Bursa Efek Indonesia Periode 2011-2015. Jurnal Nominal, 72), 111-125. Retrieved from https:/journal .uny.ac.id/index.php/ nominal/article/view/19364.

Sari, W. A., Handayani, S. R., \& Nuzula, N. F. (2016). Pengaruh Pengungkapan Corporate Social Responsibility Terhadap Kinerja Keuangan dan Nilai Perusahaan (Studi Komparatif Pada Perusahaan Multinasional yang Terdaftar di Bursa Efek Indonesia dan Bursa Efek Malaysia tahun 2012-2015). Jurnal Administrasi Bisnis, 39(2), 74-83. Retrieved from http://administ rasibisnis.studentjournal.ub.ac.id/index.php/jab/article/view/1562.

Sembiring, C. L. (2017). Manajemen Laba dan Pengungkapan Tanggung Jawab Sosial Perusahaan dengan Komisaris Independendan Kepemilikan Institusional sebagai Variabel Pemoderasi. Jurnal Berkala Akuntansi Dan Keuangan Indonesia, 2, 20-41. Retrieved from https://e-journal. unair.ac.id/BAKI/article/view/3544.

Sembiring, E. R. (2005). Karakteristik Perusahaan dan Pengungkapan KInerja Sosial: Study Empiris Pada Perusahaan yang Tercatat di Bursa Efek Jakarta. Simposium Nasional Akuntansi (SNA). Retrieved from http://mahasiswa.dinus.ac.id/docs/skripsi/jurnal/12943.pdf. 
Setyowati, V. K., Zahroh, Z. A., \& Endang, M. G. W. (2014). Pengaruh Pengungkapan Good Corporate Governance dan Corporate Social Responsibility Terhadap Nilai Perusahaan (Pada Indeks Bisnis-27 yang Terdaftar di BEI Periode 2010-2012). Jurnal Administrasi Bisnis, 15(1), 1-10. Retrieved from http://administrasibisnis.studentjournal.ub.ac.id/index.php/jab/article/view/612

Sukamulja, S. (2005). Good Corporate Governance di Sektor Keuangan: Dampak GCG Terhadap Kinerja Perusahaan (Kasus di Bursa Efek Jakarta). Benefit, 8(1), 1-25. Retrieved from http:// journals.ums.ac.id/index.php/benefit/article/view/1193.

Syafrinaldi, K. (2015). Pengaruh Good Corporate Governance dan Pengungkapan Corporate Social responsibility Terhadap Nilai Perusahaan Perbankan di Bursa Efek Indonesia Tahun 20122012. Jurnal Online Mahasiswa Fakultas Ekonomi, 2(1), 1-30. Retrieved from https://jom. unri. ac.id/index.php/JOMFEKON/article/view/8144.

Untung, Hendrik Budi. (2009). Corporate Social Responsibility. Jakarta: Sinar Grafika.

Waddock, S. A., \& Graves, S. B. (1997). The Corporate Social Performance-Financial Performance Link. Strategic Management Journal, 18(4), 303-319. https://doi.org/http://dx.doi.org /10.1002/ (SICI)1097-0266(199704)18:4\%3C303::AID-SMJ869\%3E3.0.CO;2-G.

Widyanti, R. A. Y. U. (2014). Pengaruh Profitabilitas, Dividend Payout Ratio, Dan Corporate Social Responsibility Terhadap Nilai Perusahaan Sektor Manufaktur. Jurnal Ilmu Manajemen, 2(3), 1048-1057. Retrieved from http:/jurnalmahasiswa.unesa.ac.id/index.php/jim/article/view/10219. 